\title{
TERAPI PENGGUNAAN OBAT STROKE PADA PASIEN STROKE ISKEMIK DI RSUD ABDUL WAHAB SJAHRANIE SAMARINDA
}

\author{
Renny Anggraini*, Victoria Yulita F, Muhammad Amir Masruhim \\ Laboratorium Penelitian dan Pengembangan FARMAKA TROPIS \\ Fakultas Farmasi Universitas Mulawarman, Samarinda, Kalimantan Timur \\ *email: Rhenyanggraini15@gmail.com
}

\begin{abstract}
ABSTRAK
Stroke Iskemik adalah tanda klinis disfungsi atau kerusakan jaringan otak yang disebabkan kurangnya aliran darah ke otak karena adanya penyumbatan pada pembuluh darah otak sehingga mengganggu kebutuhan darah dan oksigen di jaringan otak. Penelitian ini bertujuan untuk mengetahui karakteristik pasien dan penggunaan obat stroke pada pasien stroke iskemik yang menjalani rawat inap di Rumah Sakit Abdul Wahab Sjahranie Samarinda. Penelitian ini merupakan penelitian non ekperimental dengan rancangan analisis deksriptif menggunakan data rekam medik yang dikumpulkan secara retrospektif dan jumlah sampel dalam penelitian ini adalah 110 pasien. Pemilihan sampel penelitian dilakukan dengan rancangan non probability sampling menggunakan teknik purposive sampling. Hasil penelitian menunjukkan karakteristik pasien stroke iskemik tertinggi berdasarkan jenis kelamin adalah laki-laki $(59,09 \%)$, berdasarkan usia adalah kelompok usia 41-65 tahun (70,00\%), berdasarkan pendidikan terakhir adalah SMA atau sederajat $(20,00 \%)$ dan berdasarkan pekerjaan adalah pegawai swasta $(40,00 \%)$. Obat yang paling banyak digunakan pada terapi stroke iskemik adalah obat golongan aktivator serebral dan vasodilator perifer yaitu obat citicolin $(82,73 \%)$ dengan dosis obat $500 \mathrm{mg}$ dan lama pengobatan yang paling banyak terjadi pada hari ke $5-10$ hari $(56,37 \%)$.
\end{abstract}

Kata Kunci : Stroke iskemik, karakteristik pasien, penggunaan obat

\section{PENDAHULUAN}

Stroke merupakan penyakit atau gangguan fungsional otak berupa kelumpuhan saraf (deficit neurologic) akibat terhambatnya aliran darah ke otak. Secara sederhana stroke akut didefinisikan sebagai penyakit otak akibat terhentinya suplai darah ke otak karena sumbatan (stroke iskemik) atau perdarahan (stroke hemorrhagic).

Menurut Basjiruddin (2007) menyatakan bahwa di Amerika Serikat, stroke merupakan penyebab kematian ketiga di negara-negara industri Eropa dan sebagai penyebab utama kecacatan pada orang dewasa. Insiden global meningkat karena jumlah penduduk berusia lebih dari 65 tahun juga mengalami peningkatan dari 390 juta penduduk pada saat sekarang akan menjadi 800 juta pada tahun 2020. Stroke dapat terjadi pada semua usia terutama pasien berusia lebih dari 64 tahun yang mencapai 75\% dari seluruh kejadian stroke sedangkan di Indonesia prevalensi stroke terjadi 1-2\% dari penduduk Indonesia yaitu sekitar 2-3 juta jiwa. Hasil riset Kesehatan Dasar Departemen Kesehatan RI pada tahun 2007 menunjukkan bahwa stroke merupakan penyebab kematian terbanyak di Indonesia pada penduduk berusia diatas lima puluh tahun (Depkes, 2008).

Angka kejadian stroke terus meningkat dengan tajam, apabila tidak ada upaya penanggulangan yang lebih baik maka jumlah penderita stroke ini pada tahun 2020 
diprediksikan akan meningkat 2 kali lipat, bahkan saat ini Indonesia merupakan salah satu negara dengan jumlah penderita stroke terbesar di Asia dan keempat didunia, setelah India, Cina, dan Amerika (Feigin, 2006).

Menurut National Stroke Association-USA (NSA) stroke dibagi menjadi dua, yaitu stroke iskemik dan stroke hemoragik. Di Amerika Serikat, insiden penyakit stroke iskemik (penyumbatan) memiliki persentase terbesar yaitu $80 \%$ dan insiden penyakit stroke hemoragik antara 15\%-30\% sedangkan insiden stroke dinegara-negara berkembang seperti Indonesia untuk stroke hemoragik sekitar 30\% dan stroke iskemik 70\% (Junaidi, 2011) serta insiden stroke di Samarinda khususnya RSUD Abdul Wahab Sjahranie pada tahun 2014 hingga 30 April 2015 memiliki persentase stroke iskemik sebesar 79,07 \% dan stroke hemoragik sebesar 20,93\% dimana dari data tersebut dapat diketahui bahwa kejadian stroke iskemik memiliki proporsi yang lebih besar dibandingkan dengan stroke hemoragik.

Penjelasan di atas dapat memberikan gambaran bahwa pada kasus stroke iskemik ini membutuhkan penanganan yang baik dan serius sehingga perlu dilakukan penelitian lebih lanjut tentang gambaran karakteristik serta pengobatan stroke iskemik yang meliputi pemilihan jenis obat, golongan obat, penetapan dosis dan lama pengobatan pada pasien stroke iskemik yang di rawat inap di RSUD Abdul Wahab Sjahranie Samarinda.

\section{METODE PENELITIAN}

Penelitian ini merupakan penelitian non ekperimental dengan analisis deksriptif menggunakan data rekam medik yang dikumpulkan secara retrospektif. Penelitian dilaksanakan di bagian rekam medik rumah sakit Abdul Wahab Sjahranie Samarinda pada bulan Januari hingga bulan Februari 2016. Sampel penelitian adalah pasien stroke iskemik yang termasuk dalam kriteria inklusi dimana kriteria inklusi adalah pasien stroke iskemik yang di rawat inap di RSUD Abdul Wahab Sjahranie Samarinda dengan data rekam medik dan data laboratorium yang lengkap sedangkan kriteria eksklusi adalah data rekam medik dan data laboratorium pasien yang tidak lengkap, hilang dan tidak jelas terbaca, pasien meninggal, pasien dirujuk ke rumah sakit lain serta pasien pulang paksa. Instrumen penelitian yang digunakan berupa lembar pengumpul data yang memuat nomor rekam medik pasien, usia, jenis kelamin, pendidikan terakhir, pekerjaan, obat yang digunakan dan dosis obatnya. Data yang diperoleh selanjutnya dianalisa secara deskriptif meliputi karakteristik pasien dan penggunaan obat stroke pada pasien stroke iskemik di RSUD Abdul Wahab Sjahranie tersebut.

\section{HASIL DAN PEMBAHASAN}

Dari hasil penelitian melalui pengumpulan data secara retrospektif pada pasien stroke iskemik yang di rawat inap di RSUD Abdul Wahab Sjahranie Samarinda tahun 2014 didapatkan jumlah pasien sebanyak 913 pasien dan pasien yang memenuhi kriteria inklusi sebanyak 110 pasien. Data pasien yang memenuhi kriteria inklusi kemudian dianalisis karakteristik dan penggunaan obat stroke pada pasien stroke iskemik tersebut.

\section{Karakteristik Pasien Stroke Iskemik}

\section{Jenis Kelamin}

Distribusi pasien stroke iskemik yang terbanyak berdasarkan jenis kelamin adalah lakilaki yaitu sebanyak 65 pasien $(59,09 \%)$ (Tabel 1). 
Tabel 1. Distribusi Pasien stroke iskemik yang menjalani rawat inap di RSUD Abdul Wahab Sjahranie Samarinda tahun 2014 berdasarkan jenis kelamin

\begin{tabular}{ccc}
\hline Jenis Kelamin & Jumlah & Persentase (\%) \\
\hline Laki-laki & 65 & $59,09 \%$ \\
Perempuan & 45 & $40.91 \%$ \\
\hline Total & 110 & $100 \%$ \\
\hline
\end{tabular}

Berdasarkan tabel diatas, di ketahui bahwa pasien laki-laki $(59,09 \%)$ lebih banyak dibandingkan pasien perempuan $(40,91 \% \%)$. Hal ini menunjukkan bahwa jenis kelamin menjadi faktor resiko terjadinya stroke iskemik terutama pada laki-laki. Hasil yang sama dengan penelitian ini ditunjukkan oleh penelitian Ali (2009) dimana prevalensi stroke iskemik pada laki-laki lebih banyak dibandingkan perempuan karena laki-laki tidak memiliki hormon yang dapat meningkatkan kadar HDL darah sedangkan perempuan memiliki hormon estrogen yang dapat meningkatkan kadar HDL dalam darah yang dapat mencegah terjadinya atherosklerosis akibat terbentuknya plak-plak pada pembuluh darah sehingga laki-laki lebih berisiko mengalami stroke iskemik dibandingkan dengan perempuan tetapi ketika hormon estrogen tersebut produksinya berkurang atau bahkan tidak di produksi lagi maka risiko perempuan terserang stroke iskemik sama dengan lakilaki untuk terkena serangan stroke iskemik dan penyakit jantung (Heart and Stroke Foundation, 2010). Selain itu, tingginya angka kejadian stroke iskemik pada laki-laki kemungkinan dipengaruhi oleh faktor gaya hidup antara lain seperti merokok, minumminuman beralkohol dan stress.

\section{Usia}

Distribusi pasien stroke iskemik yang terbanyak berdasarkan usia berkisar antara usia 41-65 tahun yaitu sebanyak 77 pasien $(70,00 \%)$ (Tabel 2).

Usia merupakan salah satu faktor risiko terjadinya stroke iskemik. Pada hasil penelitian menunjukkan bahwa kejadian stroke iskemik terbanyak terjadi pada rentang usia 41-65 tahun $(70,00 \%)$ dan paling sedikit pada rentang usia 18-40 tahun $(12,73 \%)$.

Tabel 2. Distribusi Pasien stroke iskemik yang menjalani rawat inap di RSUD Abdul Wahab Sjahranie Samarinda tahun 2014 berdasarkan usia

\begin{tabular}{ccc}
\hline Usia & Jumlah & Persentase (\%) \\
\hline $18-40$ & 14 & $12,73 \%$ \\
$41-65$ & 77 & $70,00 \%$ \\
$>65$ & 19 & $17,27 \%$ \\
\hline Total & 110 & $100 \%$ \\
\hline
\end{tabular}

Hal ini sesuai dengan penelitian Misbach (2001) yang melaporkan adanya 2065 penderita stroke iskemik yang dirawat, dengan rentang usia dibawah 45 tahun sebanyak $12,9 \%$, rentang usia 45-65 tahun sebanyak 50,5\% dan diatas 65 tahun sebanyak 35,8\% Hal ini diperkirakan bahwa kejadian stroke iskemik lebih sering terjadi pada usia tua karena seiring bertambahnya usia terjadi penurunan fungsi organ dalam tubuh salah satunya terjadi penurunan aliran darah ke otak dan penurunan elastisitas arteri sehingga pembuluh darah akan berangsur angsur menyempit dan menjadi kaku. Hal ini mengakibatkan resiko hipertensi dan aterosklerosis meningkat yang dapat menyebabkan terjadinya stroke iskemik (Junaidi, 2011). 


\section{Pekerjaan}

Distribusi pasien stroke iskemik yang terbanyak berdasarkan pekerjaan adalah pegawai swasta yaitu sebanyak 44 pasien $(40,00 \%)$ (Tabel 3).

Tabel 3. Distribusi Pasien stroke iskemik yang menjalani rawat inap di RSUD Abdul Wahab Sjahranie Samarinda tahun 2014 berdasarkan pekerjaan.

\begin{tabular}{ccc}
\hline Pekerjaan & Jumlah & Persentase (\%) \\
\hline Pegawai Swasta & 44 & $40,00 \%$ \\
PNS & 17 & $15,45 \%$ \\
IRT & 7 & $6,36 \%$ \\
Pensiunan & 3 & $2,73 \%$ \\
Tidak Tercantum & 39 & $35,46 \%$ \\
\hline Total & 110 & $100 \%$ \\
\hline
\end{tabular}

Berdasarkan tabel diatas, di ketahui bahwa dari 110 pasien stroke iskemik, masingmasing mempunyai beberapa macam pekerjaan. Pekerjaan sebagai pegawai swasta sebanyak 44 pasien (40,00\%), sebagai pegawai negeri sipil sebanyak 17 pasien $(15,45 \%)$, sebagai ibu rumah tangga sebanyak 7 pasien $(6,36 \%)$, dan yang tidak bekerja atau pensiunan sebanyak 3 pasien $(2,73 \%)$ serta pekerjaan yang tidak tercantum dalam rekam medik pasien stroke iskemik sebanyak 39 pasien $(35,46 \%)$. Dari penelitian ini didapatkan hasil bahwa pasien stroke iskemik yang bekerja khususnya pegawai swasta, lebih banyak dibandingkan yang tidak bekerja. Hal ini disebabkan karena stress psikologis akibat pekerjaan yang dapat meningkatkan risiko terkena stroke iskemik. Risiko stroke iskemik akibat stress kerja lebih besar 1,4 kali pada pria dari kalangan ekonomi menengah atas.

\section{Pendidikan Terakhir}

Distribusi pasien stroke iskemik yang terbanyak berdasarkan pendidikan terakhir adalah SMA yaitu sebanyak 22 pasien $(20,00 \%)$ (Tabel 4$)$.

Tabel 4. Distribusi Pasien stroke iskemik yang menjalani rawat inap di RSUD Abdul Wahab Sjahranie Samarinda tahun 2014 berdasarkan pendidikan terakhir.

\begin{tabular}{ccc}
\hline Pendidikan Terakhir & Jumlah & Persentase (\%) \\
\hline SD & 5 & $4,55 \%$ \\
SMP & 11 & $10,00 \%$ \\
SMA & 22 & $20,00 \%$ \\
Perguruan Tinggi & 11 & $10,00 \%$ \\
Tidak Tercantum & 61 & $55,45 \%$ \\
\hline Total & 110 & $100 \%$ \\
\hline
\end{tabular}

Berdasarkan hasil penelitian tingkat pendidikan terbanyak ialah setingkat Sekolah Menengah Atas (SMA) sebanyak 22 orang $(20,00 \%)$ dan yang terendah adalah setingkat Sekolah Dasar (SD) berjumlah 5 orang (4,55\%). Hal ini tidak berarti bahwa tingkat pendidikan SMA lebih berisiko mengalami stroke iskemik, namun hanya menggambarkan bahwa pasien stroke yang dirawat di rumah sakit didominasi lulusan SMA dimana tingkat pendidikan sebagai faktor sosial ekonomi tidak berkaitan langsung dengan kejadian stroke 
iskemik. Akan tetapi, tingkat pendidikan seseorang menentukan sikap orang tersebut terhadap perilaku sehat dalam menjaga kesehatan sehingga seseorang dengan tingkat pendidikan yang lebih tinggi diharapkan mampu memahami informasi kesehatan dan mengaplikasikannya dalam kehidupan sehari-hari agar dapat menjaga kesehatan dengan baik (Notoatmodjo, 2007). Pada penelitian ini, tingkat pendidikan tertinggi pada pasien stroke iskemik adalah sarjana yang termasuk dalam kategori perguruan tinggi atau diploma yaitu sebanyak 11 pasien $(10,00 \%)$ dimana jumlah pasien ini lebih kecil dibandingkan persentase pasien stroke iskemik yang tingkat pendidikan SMA yaitu sebanyak 22 pasien $(20,00 \%)$. Akan tetapi pada golongan tingkat pendidikan yang lebih rendah seperti tamat SD dan SMP proporsi pasien stroke iskemik lebih kecil dibandingkan dengan proporsi pasien tamat SMA. Hal ini mungkin disebabkan oleh status ekonomi orang yang berpendidikan rendah tidak mampu menjangkau pelayanan kesehatan sehingga hanya sedikit dari golongan pendidikan rendah yang mendapatkan pelayanan kesehatan dan terdeteksi menderita penyakit stroke iskemik.

\section{Penggunaan Obat Stroke pada Pasien Stroke Iskemik}

\section{Golongan dan Jenis Obat}

Terapi stroke iskemik bertujuan untuk mengurangi progresifitas kerusakan neurologi, mengurangi angka kematian dan kecacatan jangka panjang serta mencegah terjadinya stroke ulangan (Fagan dan Hess, 2008). Terapi utama stroke iskemik yang digunakan pada penelitian ini adalah golongan aktivator serebral dan vasodilator perifer, antiplatelet, serta Nootropik dan Neurotropik. Persentase penggunaan terapi utama pasien stroke iskemik yang terbanyak berdasarkan golongan aktivator serebral dan vasodilator perifer adalah citicolin sebesar $82,73 \%$, berdasarkan golongan antiplatelet adalah clopidogrel sebesar $50,00 \%$, berdasarkan golongan nootropik dan neurotropik adalah piracetam sebesar 41, $82 \%$ (Tabel 5).

Tabel 5. Penggunaan terapi utama pasien stroke iskemik di RSUD Abdul Wahab Sjahranie Samarinda Periode 2014.

\begin{tabular}{lllcc}
\hline No. & \multicolumn{1}{c}{ Golongan Obat } & Jenis Obat & Jumlah Pasien & Persentase (\%) \\
\hline 1 & Aktivator Serebral dan & Citicolin & 91 Pasien & $82,73 \%$ \\
& Vasodilator Perifer & & & \\
2 & Antiplatelet & Aspilet & 45 Pasien & $40,91 \%$ \\
& & Clopidogrel & 55 Pasien & $50,00 \%$ \\
3. & Nootropik dan & Mecobalamin & 20 Pasien & $18,18 \%$ \\
& Neurotropik & Piracetam & 46 Pasien & $41,82 \%$ \\
\hline
\end{tabular}

Berdasarkan hasil penelitian, didapatkan golongan obat aktivator serebral dan vasodilator perifer yang sering digunakan adalah citicolin yaitu sebesar 82,73\%. Citicolin merupakan obat yang digunakan untuk dapat mengatasi pasien dengan kesadaran menurun yang mengakibatkan fungsi otak berkurang. Peran citikolin adalah memperbaiki membran sel dengan cara menambahsintesis phosphatidylcholine yang merupakan komponen utama membran sel terutama otak dimana dengan meningkatnya sintesis phosphatidylcholine akan berpengaruh pada perbaikan fungsi membran sel yang mengarah pada perbaikan sel. Pada level vaskuler, citikolin berperan dalam meningkatkan aliran darah otak, meningkatkan konsumsi oksigen, dan menurunkan resistensi vaskuler (Setiya, 2013). 
Citicolin merupakan obat yang dapat menghambat radikalisasi asam lemak pada keadaan penyumbatan sehingga dapat mengurangi penumpukan asam lemak pada dinding pembuluh darah (Grieb, 2014).

Antiplatelet adalah obat yang dapat menghambat agregasi trombosit sehingga menyebabkan terhambatnya pembentukan trombus pada sistem arteri. Antiplatelet ini sering digunakan pada pasien stroke iskemik untuk pencegahan stroke ulangan dengan mencegah terjadinya agregasi platelet dimana obat antiplatelet yang sering digunakan adalah clopidogrel yaitu sebesar 50,00\%. Clopidogrel dan aspirin bekerja pada faktor yang berbeda tetapi dengan cara yang sama, sebagai anti agregrasi platelet Clopidogrel adalah obat penghambat antiagregasi trombosit yang memiliki efek untuk mencegah terjadinya stroke susulan. Clopidogrel secara aktif mengurangi aktivasi agregasi platelet dengan menghambat pegikatan ADP secara selektif dan permanen menghalangi reseptor platelet $\left(\mathrm{P} 2 \mathrm{Y}_{12}\right)$. Clopidogrel digunakan pada pasien yang terindikasi alergi terhadap aspirin. Selain clopidogrel, golongan antiplatelet yang banyak digunakan adalah aspirin. Aspirin bekerja dengan mereduksi aktivasi dari platelet dengan cara menghambat COX-1 (cyclooxygenase) secara irreversible sehingga produksi $\mathrm{TXA}_{2}$ terhambat dan mengakibatkan menurunnya sintesis tromboksan dimana tromboksan dibutuhkan untuk dapat memfasilitasi agregasi platelet serta untuk menstimulasi aktivitas platelet (Dianita,2013).

Golongan nootropik dan neurotropik merupakan golongan obat yang berfungsi sebagai pemacu kerja otak serta dapat membantu melancarkan fungsi otak akibat penurunan kesadaran dimana obat golongan ini yang sering digunakan adalah piracetam sebesar $41,82 \%$. Piracetam merupakan turunan neurotransmitter penghambatan gamma aminobutyric acid (GABA) yang dapat meningkatkan aliran darah pada daerah iskemik otak yang digunakan dalam membantu meningkatkan fungsi kognitif otak yang menurun dengan bertambahnya usia serta berperan dalam memperbaiki saraf dan pembuluh darah yang mungkin berhubungan dengan pemulihan fluiditas membran (Setiya, 2013). Selain piracetam, golongan nootropik dan neurotropik yang digunakan adalah mecobalamin. Mecobalamin merupakan bentuk vitamin $\mathrm{B}_{12}$ dengan gugus metil aktif yang berperan dalam reaksi transmetilasi dan merupakan bentuk paling aktif dibandingkan dengan homolog vitamin $\mathrm{B}_{12}$ dalam hal ini kaitannya dengan metabolisme asam nukleat, protein dan lemak dimana mecobalamin dapat meningkatkan metabolisme asam nukleat, protein dan lemak.

\section{Dosis Obat Stroke pada Pasien Stroke Iskemik}

Dosis merupakan jumlah atau takaran obat yang diberikan kepada pasien dalam satuan berat, isi (volume) atau unit dimana obat citicolin dengan dosis $500 \mathrm{mg}$ lebih banyak digunakan. Persentase penggunaan dosis terapi utama pasien stroke iskemik yang terbanyak berdasarkan golongan aktivator serebral dan vasodilator perifer adalah citicolin dengan dosis $500 \mathrm{mg}$, berdasarkan golongan antiplatelet adalah clopidogrel dengan dosis $75 \mathrm{mg}$, berdasarkan golongan nootropik dan neurotropik adalah piracetam dengan dosis $1200 \mathrm{mg}$ (Tabel 6).

Hasil penelitian menunjukkan bahwa dosis obat yang banyak digunakan dalam penggunaan obat stroke iskemik adalah golongan obat aktivator serebral dan vasodilator perifer yaitu obat citicolin dengan dosis obat $500 \mathrm{mg}$ yang diberikan 2 atau 3 kali dalam sehari dimana dosis lazim yang diberikan pada manusia adalah 500-2000 mg sehingga pemberian citicolin pada pasien stroke iskemik dalam rentang yang normal.

Dosis obat clopidogrel dan aspilet yang digunakan pada pasien stroke iskemik adalah $75 \mathrm{mg}$ untuk obat clopidogrel yang diberikan 1 kali dalam sehari dan $80 \mathrm{mg}$ untuk obat aspilet yang diberikan 1 atau 2 kali dalam sehari dimana dosis lazim yang diberikan adalah $75 \mathrm{mg}$ untuk obat clopidogrel dan 75-300 mg untuk obat aspilet sehingga pemberian 
clopidogrel dan aspilet pada pasien stroke iskemik dalam rentang yang normal (Perdossi, 2004).

Tabel 6. Penggunaan dosis obat pada pasien stroke iskemik di RSUD Abdul Wahab Sjahranie Samarinda Periode 2014.

\begin{tabular}{|c|c|c|c|c|c|}
\hline No & Golongan Obat & Jenis Obat & Dosis Obat & $\begin{array}{l}\text { Frekuensi } \\
\text { Pemberian }\end{array}$ & $\begin{array}{l}\text { Jumlah } \\
\text { Pasien }\end{array}$ \\
\hline \multirow[t]{3}{*}{1} & \multirow{3}{*}{$\begin{array}{l}\text { Aktivator Serebral } \\
\text { dan Vasodilator } \\
\text { Perifer }\end{array}$} & \multirow[t]{3}{*}{ Citicolin } & $250 \mathrm{mg}$ & $2 \times 1$ & 10 \\
\hline & & & $500 \mathrm{mg}$ & $2 \times 1$ & 80 \\
\hline & & & & $3 \times 1$ & 9 \\
\hline \multirow[t]{3}{*}{2} & \multirow[t]{3}{*}{ Antiplatelet } & \multirow[t]{2}{*}{ Aspilet } & \multirow[t]{2}{*}{$80 \mathrm{mg}$} & $1 \times 1$ & 44 \\
\hline & & & & $2 \times 1$ & 7 \\
\hline & & Clopidogrel & $75 \mathrm{mg}$ & $1 \times 1$ & 55 \\
\hline \multirow[t]{7}{*}{3.} & \multirow{7}{*}{$\begin{array}{l}\text { Nootropik dan } \\
\text { Neurotropik }\end{array}$} & \multirow[t]{4}{*}{ Mecobalamin } & $500 \mathrm{mg}$ & $2 \times 1$ & 10 \\
\hline & & & & $3 \times 1$ & 4 \\
\hline & & & $1000 \mathrm{mg}$ & $1 \times 1$ & 1 \\
\hline & & & & $2 \times 1$ & 5 \\
\hline & & \multirow[t]{3}{*}{ Piracetam } & $800 \mathrm{mg}$ & $2 \times 1$ & 14 \\
\hline & & & $1200 \mathrm{mg}$ & $1 \times 1$ & 39 \\
\hline & & & & $2 \times 1$ & 2 \\
\hline
\end{tabular}

Dosis obat mecobalamin dan piracetam yang digunakan pada pasien stroke iskemik adalah 500-1000 mg untuk obat mecobalamin yang diberikan 1- 3 kali dalam sehari dan 800-1200 mg untuk obat piracetam yang diberikan 1 atau 2 kali dalam sehari dimana pemberian mecobalamin dan piracetam pada pasien stroke iskemik dalam rentang yang normal.

\section{Lama Pengobatan pada Pasien Stroke Iskemik}

Lama pengobatan pasien stroke iskemik dikatagorikan dalam jumlah hari dimana lama pengobatan didapatkan dari tanggal keluar rumah sakit dikurangi dengan tanggal masuk rumah sakit. Berdasarkan lama pengobatan pasien, ada yang tergolong paling lama dan paling cepat (Tabel 7).

Tabel 7. Lama pengobatan Pasien Stroke Iskemik Rawat Inap di RSUD Abdul Wahab Sjahranie Samarinda Periode 2014.

\begin{tabular}{lcc}
\hline Lama Hari Pengobatan & Jumlah & Persentase \\
\hline$<5$ hari & 35 & $31,82 \%$ \\
$5-10$ hari & 62 & $56,37 \%$ \\
$11-16$ hari & 6 & $5,45 \%$ \\
$17-21$ hari & 6 & $5,45 \%$ \\
$>$ 21 hari & 1 & $0,91 \%$ \\
\hline Total & 110 & $100 \%$ \\
\hline
\end{tabular}


Dari hasil penelitian didapatkan sebagian besar pasien stoke iskemik menjalani pengobatan selama 5- 10 hari sebanyak 62 pasien (56,37\%) dimana pasien yang paling lama di rawat adalah pasien yang dirawat selama 26 hari dengan penyakit penyerta ulkus dekubitus dan tergolong lansia sedangkan pasien yng tergolong singkat pengobatannya adalah pasien dengan lama pengobatan selama 2 hari dan tidak memiliki penyakit penyerta yang dapat memperparah stroke iskemiknya serta usia dari pasien ini juga trgolong usia dewasa sehingga proses penyembuhannya cepat. Dari kedua contoh diatas, dapat dilihat bahwa lama pengobatan pasien stroke iskemik cenderung membutuhkan waktu yang lama. Selain dari usia pasien, hal yang perlu diperhatikan adalah kondisi pasien dan tingkat keparahan penyakit penyerta (Astutik, 2013).

\section{KESIMPULAN}

Berdasarkan hasil penelitian yang telah dilakukan di RSUD Abdul Wahab Sjahranie Samarinda periode 2014 dapat disimpulkan bahwa:

1. Karakteristik pasien stroke iskemik tertinggi berdasarkan jenis kelamin adalah laki-laki $(59,09 \%)$, berdasarkan usia adalah kelompok usia 41-65 tahun $(70,00 \%)$, berdasarkan pendidikan terakhir adalah SMA atau sederajat $(20,00 \%)$ dan berdasarkan pekerjaan adalah pegawai swasta $(40,00 \%)$

2. Persentase terapi penggunaan obat stroke pada pasien stroke iskemik yang paling banyak digunakan adalah obat golongan aktivator serebral dan vasodilator perifer yaitu obat citicolin $(82,73 \%)$ dengan dosis obat $500 \mathrm{mg}$, berdasarkan golongan antiplatelet yaitu obat clopidogrel $(50,00 \%)$ dengan dosis obat $75 \mathrm{mg}$ serta berdasarkan golongan Nootropik dan Neurotropik yaitu obat piracetam (41,82\%) dengan dosis obat $1200 \mathrm{mg}$.

3. Lama pengobatan pasien terbanyak pada rentang $5-10$ hari sebesar $56,37 \%$.

\section{DAFTAR PUSTAKA}

Ali, M., 2009. Stroke Outcome In Clinical Trial Patients Deriving From Different Countries. Stroke 40:35-40.

Astutik, Widi., Didik, H., Nailis, S. 2013. Penggunaan Obat Golongan Diuretik pada Pasien Stroke Iskemik di Instalasi Rawat Inap Rsu Dr. Saiful Anwar Malang. Media Farmasi. (10)2.

Basjiruddin. 2007. Diabetes Mellitus And Stroke. Medan: Neurology Up Date

Departemen Kesehatan RI, 2008. Laporan Hasil Riset Kesehatan Dasar (Riskesdas) Indonesia Tahun 2007. Jakarta: Badan Penelitian dan Pengembngan Departemen Kesehatan RI.

Dianita, Sari., Pagan, P., Nelly, A. 2013. Perbandingan Efektivitas Asetosal dan Kombinasi Asetosal-Klopidogrel terhadap Pasien Stroke Iskemik Akut. Berkala Kedokteran. (9) 2:109-118

Feigin, Valery. 2006. Stroke, Panduan Bergambar Tentang Pencegahan dan Pemulihan Stroke. 2nd ed. Jakarta: PT Bhuana Ilmu Populer.

Grieb, P.2014. Neuroprotective Properties of Citicolin: Facts Doubts and Unrsoved Issues. CND Drugs (2014) 28.

Heart and Stroke Foundation. 2010. A Perfect Storm of Heart Disease Looming On Our Horiz

Junaidi, 2011. Stroke Waspadai Ancamannya. Yogyakarta: Andi Offset.

Misbach,Jusuf dan Ali,Wendra. 2001. Stroke in Indonesia: A first large prospective hospital-based study of acute stroke in 28 hospitals in Indonesia. Journal of Clinical Neuroscience. (8)3.

Notoatmodjo, S. 2007. Promosi Kesehatan dan Ilmu Perilaku. Jakarta: Rineka Cipta.

Perdossi, 2004. Guideline stroke. Jakarta: Perhimpunan Dokter Spesialis Saraf Indonesia. 
Setiya, D., Didik, H., dan Nailis, S. 2013. Study Penggunaan Obat Neuroprotektan pada Pasien Stroke Iskemik . Pharmacy. 10 (2). Halaman 6. 